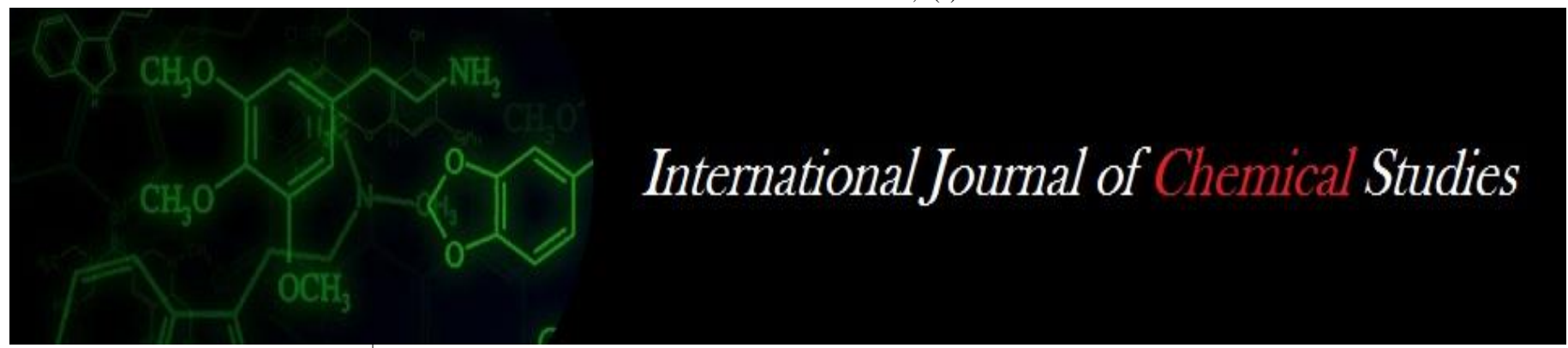

P-ISSN: 2349-8528

E-ISSN: 2321-4902

www.chemijournal.com

IJCS 2020; 8(5): 1607-1610

(C) 2020 IJCS

Received: 28-07-2020

Accepted: 30-08-2020

Naresh Kumar Bhadana

College of Agriculture, S.V.B.P.

University of Agri. \& Tech.,

Meerut, Uttar Pradesh, India

Gopal Singh

College of Agriculture, S.V.B.P.

University of Agri. \& Tech.,

Meerut, Uttar Pradesh, India

Deepak Kumar

College of Agriculture, S.V.B.P.

University of Agri. \& Tech.,

Meerut, Uttar Pradesh, India

Seweta Srivastava

School of Agriculture, Lovely

Professional University,

Phagwara, Punjab, India

\section{Evaluation of chemicals and antibiotics against green mold and bacterial rot of Pleurotus spp}

\author{
Naresh Kumar Bhadana, Gopal Singh, Deepak Kumar and Seweta \\ Srivastava
}

DOI: https://doi.org/10.22271/chemi.2020.v8.i5v.10532

\begin{abstract}
The genus Pleurotus is most exploitable xylotrophic fungi, with valuable biotechnological, medical, and nutritional properties. The relevant features of the representatives of this genus to provide attractive lowcost industrial tools have been reported in numerous studies to resolve the pressure of ecological issues. Additionally, a number of Pleurotus species are highly adaptive, do not require any special conditions for growth, and possess specific resistance to contaminating diseases and pests.Even then species of this edible mushroom can often be affected by some bacterial, mold and virus diseases that rather frequently cause dramatic production loss.In the present experiment we evaluated the efficacy of different chemicals and antibiotics against green mold and bacterial rot of Pleurotus florida and Pleurotus djamor. From this experiment it was concluded that the maximum number of fruiting body in both Pleurotus spp. are taking in the spray of Streptomycin $400 \mathrm{ppm}+$ Carbandazim $0.0025 \%$ (21.67 and 22.33), respectively.
\end{abstract}

Keywords: Antibiotics, black rot, chemicals, green mold, Pleurotus spp.

\section{Introduction}

The Pleurotus genus is one of most extensively studied white-rot fungi due to its exceptional ligninolytic properties. The oyster mushroom (Pleurotus spp.) is an edible mushroom in both forms fresh as well as dry. It has been perceived as an exceptionally potential converter of agricultural waste into profitable protein (Rezal, 2019) ${ }^{[13]}$. It is a rich source of nutrients, particularly proteins, minerals as well as vitamins B, C and D. The unique properties of Pleurotus species widely used in many environmental technologies, such as organic solid waste recycling, chemical pollutant degradation, and bioethanol production (Sekan et al. 2019). In basidiomycete fungi, intensive cultivations of edible mushrooms can often be affected by some bacterial, mold and virus diseases that rather frequently cause dramatic production loss. These infections are facilitated by the particular conditions under which mushroom cultivation is commonly carried out such as warm temperatures, humidity, carbon dioxide (CO2) levels and presence of pests (Bellettini et al 2018) ${ }^{[1]}$.

Trichoderma spp. is the cause of the green mold disease in mushroom cultivation production. Many disinfection treatments are commonly applied to lignocellulose substrates to prevent contamination. Mushroom growers are usually worried about the contaminations that may occur after these treatments during handling or spawning (Colavolpe et al. 2014) ${ }^{[3]}$. Green mold causes economic losses not only in Agaricus but also in Pleurotus and Lentinula cultivation. Sharma and Vijay (Sharma and Vijay, 1996) ${ }^{[15]}$ reported a green mold attack in oyster mushroom in North America. Serious cases of green mold diseases in P. ostreatus in mushroom farms were recently detected in South Korea, Italy, Hungary and Romania (Hatvani et al., 2007) ${ }^{[6]}$. Komón-Zelazowska, et al. (2007) ${ }^{[8]}$, determined that the causal agents of this disease were two genetically closely related, but phenotypically strongly different, species of Trichoderma, which have been described as Trichoderma pleurotum and Trichoderma pleuroticola.

Bacteriosis is an unpredictable disease that can occur during the first or second sporophore flush, causing great yield loss. Destructive disease levels are induced by environmental conditions occurring at high relative humidity levels in growing chambers. Favorable to bacterial blotch outbreaks are the excess of water in the casing layer and a low aeration rate in the growing-house. These conditions can induce the occurrence of morphological variants or
Corresponding Author: Seweta Srivastava School of Agriculture, Lovely Professional University, Phagwara, Punjab, India 
aggressive pathovars of Pseudomonas reactans and Pseudomonas tolaasii (Moquet et al. 1996) ${ }^{[10]}$.

Various treatments are used for the preparation of substrate for mushroom cultivation to eliminate competitive fungi. They are: steam sterilization, steam pasteurization, hot water immersion and chemical treatment (Jaramillo and Albertó, 2013) ${ }^{[17]}$; but they are not always successful. Contaminations according to mushroom growers may even occur sporadically after these treatments during handling or spawning. The purpose of this paper is to estimate the effect of some chemicals and antibiotics against green mold and bacterial rot of Pleurotus florida and Pleurotus djamor.

\section{Materials and Methods}

The experiments were conducted in Mushroom Laboratory of Department Plant Pathology, S. V. P. University of Agriculture \& Technology, Meerut, U.P. on the Western side of the Delhi-Dehradun high way at a distance of $10.0 \mathrm{~km}$ away in the north of Meerut city. The culture of different species of Pleurotus viz. P. florida and P. djamor included in the present investigation were collected from Mushroom Research and Training Centre, G. B. P. U. A. \& T, Pantnagar and C.S.A.U.A \&T, Kanpur.

In the present experiment, different chemicals and antibiotics (i.e., Carbendazim 0.0025\%, Streptomycin $400 \mathrm{ppm}$ and Carbendazim $0.0025 \%$ 1+ Streptomycin 400 ppm) were used in major disease management at their different concentration and combination. Observations were recorded as total yield (gm/kg dry wheat straw), days for cropping period (DFCP), number of pinhead initiation (NGB) and average weight of fruiting body $(\mathrm{g} / \mathrm{FB})$.

\section{Statistical analysis of data}

Data with appropriate transformations were analyzed with the help of analysis of variance table wherever required. The $\mathrm{F}$ value was tested and critical difference $(C D)$ was calculated at 5 per cent of significance for comparing treatment means (Gomez and Gomez, 1996; Chandel, 2002) ${ }^{[4,2]}$.

\section{Results and Discussion}

\section{Disease management through chemicals and antibiotic}

As shown in Table - 1 and 2 \& Fig. 1, 2 green mould caused by Trichoderma spp., and bacterial rot caused by Pseudomonas spp. they attack on substrates, of pinhead and fruiting body of both Pleurotus spp. These were reported during September to December (i.e. cropping period). The minimum incidence of green mould (4.00 and 4.67\%), and bacterial rot $(1.33$ and $3.67 \%)$ were found in the treatment where Carbendazim 50\% WP were sprayed two times @ 0.0025 per cent followed by two time spraying of Streptomycin $400 \mathrm{ppm}$ in which disease incidence was as green mould (19.00 and $15.33 \%)$, and bacterial rot (11.67 and $10.33 \%$ ) and spraying of Carbandazim $0.0025 \%$ +Streptomycin $400 \mathrm{ppm}$ were spraying two time in which disease incidence was as green mould ( 8.50 and $8.33 \%$ ), and bacterial rot $(3.67$ and $6.33 \%$ )species of $P$. florida and $P$. djamor, respectively. The higher number of days for cropping period (72.67 and 71.33) was found in one time spray of Carbandazim $0.0025 \%$ + Streptomycin 400 ppm followed by one time spray of Streptomycin 400 ppm(71.67 and 69.33). The maximum number of fruiting body in both Pleurotus spp. are taking in the spray of Streptomycin 400 ppm + Carbandazim 0.0025\% (21.67 and 22.33), respectively. Maximum yield are found in the two time spray of Carbandazim $0.0025 \%$ + Streptomycin 400 ppm (570 and 473.3followed by one time spray of Carbandazim $0.0025 \%+$ Streptomycin $400 \mathrm{ppm}$ (543.00 and $460 \mathrm{~g} / \mathrm{kg}$ ). In both Pleurotus spp. respectively while the lowest yield (380.00 and $320.00 \mathrm{~g} / \mathrm{kg}$ of dry substrate was harvested in control.

The commercial production of oyster mushroom has been seriously affected by green mold epidemics. The causal agents of green mold disease of cultivated oyster mushroom are Trichoderma spp. (T. asperellum, T. atroviride, $T$. citrinoviride, T. hazianum, T. longibrachiatum, T. pleurotum, T. pleuroticola and $T$. virens). Trichoderma species are asexual, soil-inhabiting filamentous fungi with teleomorphs belonging to the genus Hypocrea (Ascomycota, Pyrenomycetes, Hypocreales, Hypocreaceae). Trichoderma pleurotum has been found only on cultivated P. ostreatus and its substrate. In contrast, Trichoderma pleuroticola has been found both on wild and cultivated $P$. ostreatus, as well as on the natural and productive substratum of the oyster mushroom (Kredics et al. 2009) ${ }^{[9]}$. Trichoderma green mold infection in edible basidiomycetes has been known for a long time (Sinden and Hauser, 1953) ${ }^{[16]}$.

The disease is characterized by the formation of brown to black lesions on mushroom caps and by bacterial growth in and discoloration of the stipes. These lesions consist of slightly concave spots, which can be round or spreading (Hans et al. 2012) ${ }^{[5]}$. The affected areas are sunken and covered with sticky material. However, the disease affects only the top external layers of the pileus tissues and is restricted to 2-3 $\mathrm{mm}$ below the pileus surface (Zhang et al. 2007) ${ }^{[18]}$.

Several chemicals, disinfectants and antibiotics have been studied for their potential to control bacte-rial blotch, but none has been found to be fully effective and non-toxic to the crop or consumers (Munjal et al. 1989; Vantomme et al. 1989) [11, 17]. Hence, the development of resistant mushroom strains, as well as biological control, remain the most promising approaches to combat bacterial rot and green mold disease.

Table 1: Chemical and Antibiotic management of diseases (green mould,and bacterial rot) of $P$. florida in crop room.

\begin{tabular}{|c|c|c|c|c|c|c|c|c|}
\hline \multirow{2}{*}{ S. No. } & \multirow{2}{*}{$\begin{array}{c}\text { Carbendazim+ Streptomycin } \\
\text { Concentration }(\%)\end{array}$} & \multirow{2}{*}{$\begin{array}{l}\text { No. of } \\
\text { Spray }\end{array}$} & \multicolumn{2}{|c|}{ Disease Incidence (\%) } & \multirow[t]{2}{*}{ DFCP } & \multirow[t]{2}{*}{ NOFB } & \multirow[t]{2}{*}{$\begin{array}{c}\text { Yield (g/kg dry } \\
\text { substrate) }\end{array}$} & \multirow[t]{2}{*}{$\begin{array}{c}\text { Biological } \\
\text { efficiency }(\%)\end{array}$} \\
\hline & & & Green mould & Bacterial rot & & & & \\
\hline 1. & \multirow{2}{*}{ Carbandazim $0.0025 \%$} & One & 27.00 & 19.67 & 70.67 & 16.33 & 430.00 & 43.00 \\
\hline 2. & & Two & 24.00 & 15.33 & 69.00 & 19.33 & 466.66 & 46.66 \\
\hline 3. & \multirow[b]{2}{*}{ Streptomycin 400 ppm } & One & 19.00 & 11.67 & 71.67 & 20.00 & 490.00 & 49.00 \\
\hline 4. & & Two & 13.00 & 9.33 & 68.00 & \begin{tabular}{|l|}
21.33 \\
\end{tabular} & 523.33 & 52.33 \\
\hline 5. & \multirow{2}{*}{$\begin{array}{c}\text { Carbandazim } 0.0025 \% 1+ \\
\text { Streptomycin } 400 \mathrm{ppm}\end{array}$} & One & 8.50 & 3.67 & 71.67 & 20.33 & 543.33 & 54.33 \\
\hline 6. & & Two & 4.00 & 1.33 & 67.00 & 21.67 & 570.00 & 57.00 \\
\hline 7. & control & & 37.00 & 29.00 & 70.00 & 13.33 & 380.00 & 38.00 \\
\hline \multicolumn{2}{|r|}{$\mathrm{CD}$ at $5 \%$} & - & \multicolumn{2}{|r|}{ 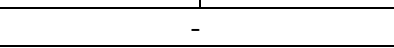 } & 1.270 & 3.175 & 13.912 & - \\
\hline
\end{tabular}

Average of three replications

$\mathrm{DFCP}=$ Days for cropping period $\mathrm{NOFB}=$ Number of fruiting body 
Table 2: Chemical and Antibiotic management of diseases (green mould, and bacterial rot) of $P$. djamor in crop room

\begin{tabular}{|c|c|c|c|c|c|c|c|c|}
\hline \multirow[b]{2}{*}{ S. No. } & \multirow[b]{2}{*}{$\begin{array}{c}\text { Carbendazim+ Streptomycin } \\
\text { Concentration }(\%)\end{array}$} & \multirow[b]{2}{*}{$\begin{array}{l}\text { No. of } \\
\text { Spray }\end{array}$} & \multicolumn{2}{|c|}{ Disease Incidence (\%) } & \multirow[b]{2}{*}{ DFCP } & \multirow[b]{2}{*}{ NOFB } & \multirow[b]{2}{*}{$\begin{array}{l}\text { Yield (g/kg dry } \\
\text { substrate) }\end{array}$} & \multirow[b]{2}{*}{$\begin{array}{c}\text { Biological efficiency } \\
(\%)\end{array}$} \\
\hline & & & $\begin{array}{l}\text { Green } \\
\text { mould }\end{array}$ & $\begin{array}{l}\text { Bacterial } \\
\text { rot }\end{array}$ & & & & \\
\hline 1. & \multirow{2}{*}{ Carbandazim $0.0025 \%$} & One & 20.67 & 14.00 & 63.67 & 12.33 & 400.00 & 40.00 \\
\hline 2. & & Two & 13.33 & 12.67 & 65.33 & 14.67 & 413.33 & 41.33 \\
\hline 3. & \multirow{2}{*}{ Streptomycin $400 \mathrm{ppm}$} & One & 15.33 & 10.33 & 67.00 & 16.33 & 436.66 & 43.66 \\
\hline 4. & & Two & 12.00 & 8.00 & 69.33 & 18.67 & 450.00 & 45.00 \\
\hline 5. & \multirow{2}{*}{$\begin{array}{c}\text { Carbandazim } 0.0025 \% 1+ \\
\text { Streptomycin } 400 \mathrm{ppm}\end{array}$} & One & 8.33 & 6.33 & 70.67 & 20.67 & 460.00 & 46.00 \\
\hline 6. & & Two & 4.67 & 3.67 & 71.33 & 22.33 & 473.33 & 47.33 \\
\hline 7. & control & - & 25.00 & 18.33 & 60.00 & 11.00 & 320.00 & 32.00 \\
\hline \multicolumn{2}{|r|}{ CD at $5 \%$} & - & & & 1.402 & 1.148 & 14.944 & - \\
\hline
\end{tabular}

Average of three replications

$\mathrm{DFCP}=$ Days for cropping period, NOFB= Number of fruiting body

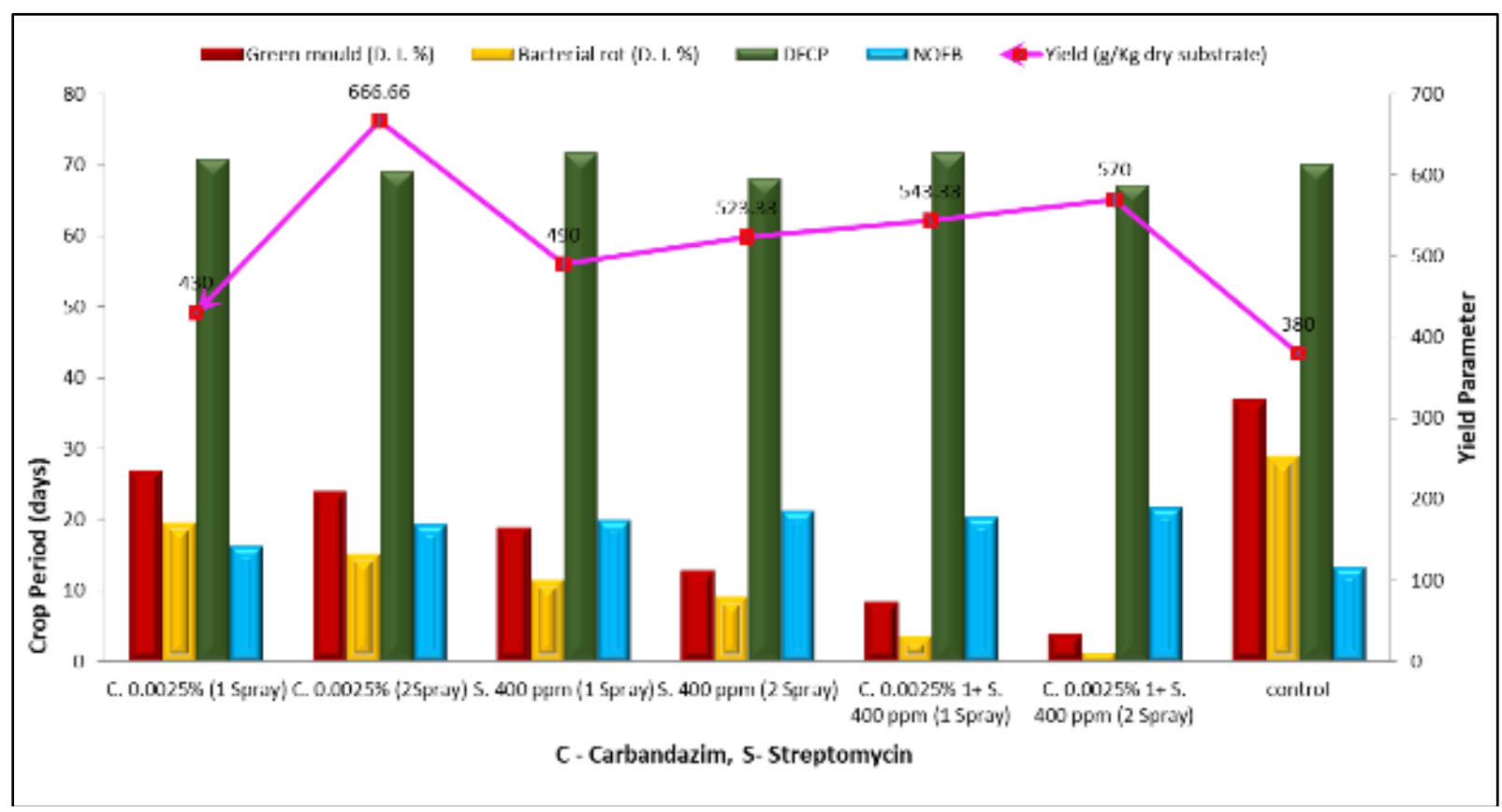

Fig 1: Chemical and antibiotic management of disease (green mold \& bacterial rot) of $P$. florida

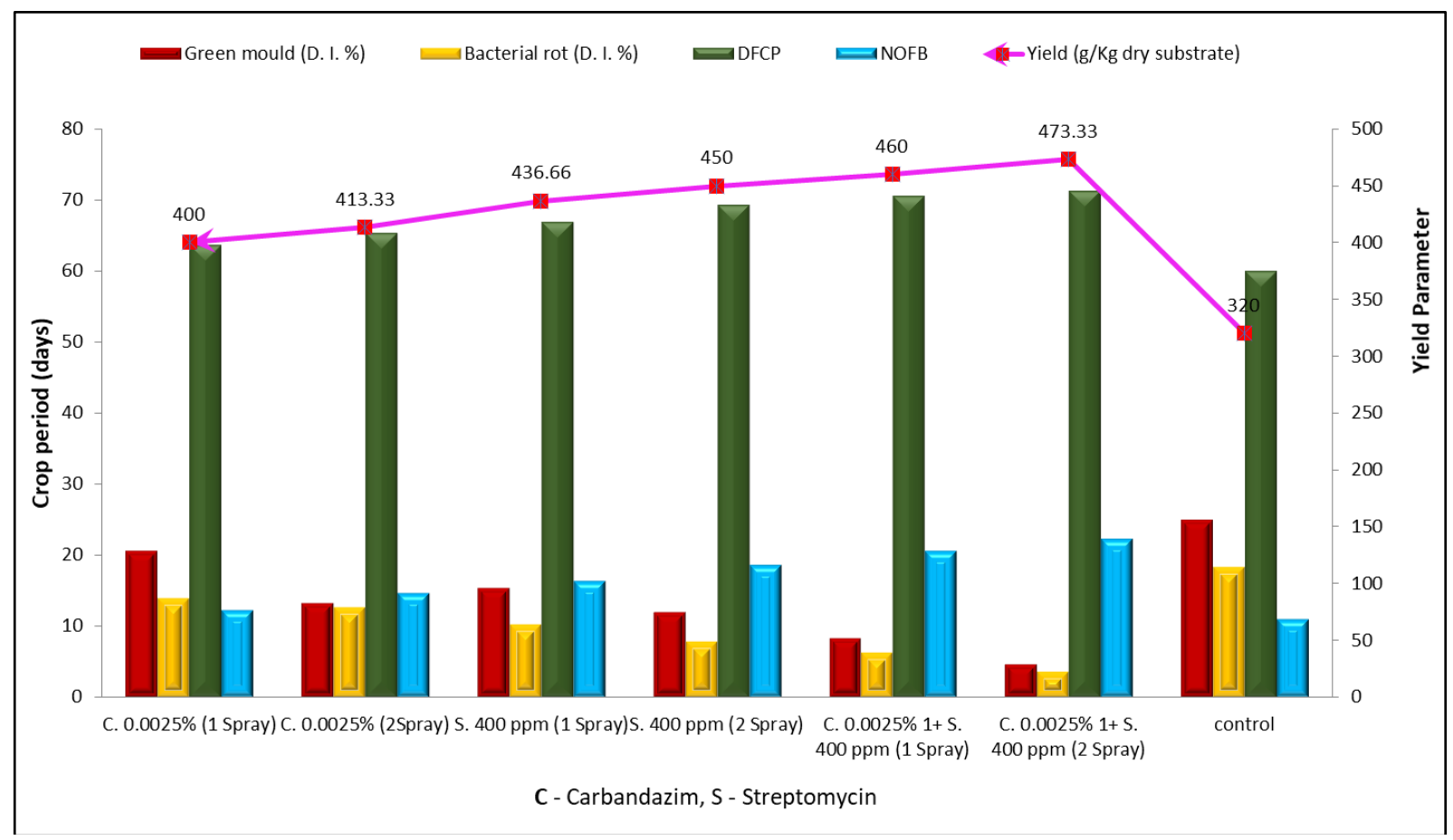

Fig 2: Chemical and antibiotic management of disease (green mold \& bacterial rot) $P$. djamor 


\section{Conclusions}

Intensive cultivation of edible mushrooms can often be affected by some bacterial, fungal and viral diseases that, rather frequently, cause dramatic production loss. These infections are facilitated by the particular conditions under which the mushroom cultivation is commonly carried out, such as warm temperatures, high humidity and a low aeration rate. The unhygienic conditions of mushroom cultivation provide a congenial atmosphere for many diseases and pests. Therefore, a clean environment is absolutely essential to mushroom production. The important considerations include previously cleaned implements and maintaining overall hygiene. This article argues that an understanding of the symptoms and treatment controls are needed for a suitable and efficient production of Pleurotus spp.

\section{References}

1. Bellettini MB, Bellettini B, Fiorda FA, Pedro AC, Bach, F, Fabela-Morón MF et al. Diseases and pests noxious to Pleurotus spp. mushroom crops. Rev Argent Microbiol. 2018; 50(2):216-226.

2. Chandel SRS. A handbook of agricultural statistics. 2002 Edn. Achal Prakashan Mandir, India. 2002, A-99-A-101.

3. Colavolpe MB, Mejía SJ, Albertó E. Efficiency of treatments for controlling Trichoderma spp. during spawning in cultivation of lignicolous mushrooms. Braz J Microbiol. 2014; 45(4):1263-1270.

4. Gomez KA, Gomez AA. Statistical Procedures for Agricultural Research. An International Rice Research Institute Book, A Wiley-intersclence Publication, John Wiley \& Sons, New York, 1996.

5. Han HS, Jhune CS, Cheong JC, Oh JA, Kong WS, Cha JS, Lee CJ. Occurrence of black rot of cultivated mushrooms (Flammulina velutipes) caused by Pseudomonas tolaasii in Korea. Eur J Plant Pathol, 2012; 133:527-535.

6. Hatvani L, Antal $\mathrm{Z}$, Manczinger L, Szekeres A, Druzhinina IS, Kubicek CP, Nagy A et al. Green mold diseases of Agaricus and Pleurotus spp. are caused by related but phylogenetically different Trichoderma species. Phytopathology. 2007; 97:532-537.

7. Jaramillo S, Albertó E. Heat treatment of wheat straw by immersion in hot water decreases mushroom yield in Pleurotus ostreatus. Rev Iberoam Micol. 2013; 30(2):125-129.

8. Komon-Zelazowska M, Bissett J, Zafari D, Hatvani L, Manczinger L, Woo S et al. Genetically closely related but phenotypically divergent Trichoderma species causes green mold diseases in oyster mushroom farms worldwide. Applied \& Environmental Microbiology. 2007; 73(22):7415-7426.

9. Kredics L, Kocsubé S, Nagy L, Komoń-Zelazowska M, Manczinger L, Sajben E et al. Molecular identification of Trichoderma species associated with Pleurotus ostreatus and natural substrates of the oyster mushroom. FEMS Microbiol Lett. 2009; 300:58-67.

10. Moquet F, Mamoun M, Olivier JM. Pseudomonas tolaasii and tolaasin: comparison of symptom induction on a wide range of Agaricus bisporus strains. FEMS Microbiol Lett. 1996; 142:99-103.

11. Munjal A, Khanna PK, Garcha HS. In vitro chemical and biological control of bacterial blotch of Agaricus bisporus (Sing.) Lange. Mushroom Sci. 1989; 12:667677.
12. Osdaghi E, Martins SJ, Ramos-Sepulveda L, Vieira FR, Pecchia JA, Beyer DM et al. 100 years since Tolaas: Bacterial blotch of mushrooms in the $21^{\text {st }}$ century. Plant Disease. 2019; 103:2714-2732.

13. Rezal, Kumar B, Kumar V, Srivastava S, Singh VP. Evaluation on different media, $\mathrm{pH}$ and temperature levels on mycelial growth of oyster mushroom (Pleurotus florida). Plant Cell Biotechnology and Molecular Biology. 2019; 20(5, 6):254-260.

14. Sekan AS, Myronycheva OS, Karlsson O, Gryganskyi AP, Blume YB. Green potential of Pleurotus spp. in biotechnology. Peer J 2019; 7:e6664 DOI 10.7717/peerj.6664

15. Sharma SR, Vijay B. Yield loss in Pleurotus ostreatus spp. caused by Trichoderma viride. Mushroom Res. 1996; 5:19-22.

16. Sinden J, Hauser E. Nature and control of three mildew diseases of mushrooms in America. Mushroom Sci. 1953; 2:177-180.

17. Vantomme R, Overstijns A, Goor M, Kersters K, De Ley J. Routine diagnosis and sensitivity to chemical compounds of phytopathogenic and saprophytic pseudomonads from cultivated mushrooms. Mushroom Sci. 1989; 12:701-710.

18. Zhang RY, Hu DD, Zuo XM, Wang HX, Jiang RB. Research advancement on brown blotch disease of oyster mushroom and button mushroom. Acta Phytophyl Sin. 2007; 34:549-554. 